\title{
Penerapan PSAK No.45 tentang Pelaporan Keuangan Organisasi Nirlaba Yayasan Pendidikan Pondok Pesantren Al-Khairiyah
}

\author{
Intan Devi Atufah ${ }^{1 *}$, Norita Citra Yuliarti² ${ }^{2}$ Dania Puspitasari ${ }^{3}$ \\ 1,2,3 Jurusan Akuntansi, Fakultas Ekonomi, Universitas Muhammadiyah Jember
}

\section{A R T I C L E I N F O}

Article history:

Received 19 May 2018

Received in revised form

10 June 2018

Accepted 12 July 2018

Available online 25 August 2018

Kata Kunci:

PSAK No.45, Nirlaba,

Laporan Keuangan,

Akuntansi

Keywords:

SFAS 45, Nonprofit, Finacial statement, Accounting

\begin{abstract}
A B S T R A K
Tujuan penelitian ini adalah untuk mengetahui apakah penerapan pelaporan keuangan pada Yayasan Pendidikan Pondok Pesantren Al-Khairiyah telah sesuai dengan apa yang telah tercantum pada PSAK No. 45. Metode penelitian deskriptif dengan teknik analisis kualitatif yang sifatnya menguraikan, menggambarkan serta mengkrontruksikan suatu data. Hasil penelitian menunjukkan laporan keuangan yang ada di Yayasan Pendidikan Pondok Pesantren AlKhairiyah belum sesuai dengan penyusunan laporan keuangan berdasarkan format laporan keuangan nirlaba yang ada pada PSAK No. 45. Laporan keuangan yang ada berupa laporan arus kas mengenai pengeluaran dan pemasukan menurut pemahaman mereka. Yayasan Pendidikan Pondok Pesantren Al-Khairiyah tidak menyajikan laporan posisi keuangan, laporan aktivitas, laporan arus kas, dan catatan atas laporan keuangan. Penyusunan laporan keuangan Yayasan Pendidikan Pondok Pesantren Al-Khairiyah sebaiknya berpedoman dan mengikuti ketentuan yang telah ditetapkan oleh Ikatan Akuntan Indonesia (IAI) yang tertuang dalam PSAK No. 45 agar informasi yang disajikan dalam laporan keuangan lebih jelas, relevan dan memiliki daya banding yang tinggi.
\end{abstract}

\section{A B S T R A C T}

The purpose of this study was to determine whether application of the financial reporting on Educational Foundation Boarding School Al-Khairiyah with what has been stated in SFAS 45. Descriptive research methods with qualityve analysis techniques outlines, describe and recontruct a data. The result showed that the financial statement in accordance with the Educational Foundation Boarding School Al-Khairiyah yet financial statement based nonprofit financial statement formats that exist in SFAS 45. The financial statements of which there are some cash flow statements regarding expenditures and income to their understanding. Educational Foundation Boarding School AlKhairiyah does not present a statement of financial position, statement of activities, statementof cash flows, and notes to the financial statements. The preparation of financial statement sshould be guided by Educational Foundation Boarding School Al-Khairiyah and follow the conditions set by the Indonesian Institute of Accountants (IAI) contained in SFAS 45 that the information presented in the financial statement be clear, relevant and has a high appeal.

\footnotetext{
* Corresponding author.

E-mail addresses: intandeviatufah51@gmail.com (Intan Devi Atufah)
} 


\section{Pendahuluan}

Organisasi nirlaba menerapkan prinsip keterbukaan dan akuntabilitas pada masyarakat, maka pihak manajemen melakukan pembenahan administrasi, termasuk publikasi pertanggungjawaban laporan keuangan setiap tahun. Laporan keuangan yang baik adalah laporan keuangan yang terhindar dari salah saji material, mudah dimengerti dan tentunya harus sesuai dengan Standart Akuntansi Keuangan (SAK No 1). Laporan keuangan tidak hanya dibuat oleh organisasi yang berorientasi laba, organisasi nirlaba juga memerlukan laporan keuangan guna mengetahui kegiatan organisasi dalam satu periode dan kemampuan organisasi dalam memberikan pelayanan, penyaluran dana dan kegiatan sosial lainnya kepada pihak yang membutuhkan.

Organisasi nirlaba dalam melaksanakan program-programnya menggunakan sumber daya yang berasal dari masyarakat, maka dari pertanggungjawaban laporan keuangannya harus bersifat terbuka dan akuntabilitas kepada masyarakat. Masing-masing organisasi nirlaba memiliki karakteristik yang unik dan masih perlu dilakukan penyempurnaan berkaitan dengan standarisasi pelaporan keuangannya. Oleh karena itu, laporan keuangan yang disajikan juga akan disesuaikan dengan karakteristik organisasi namun tetap pada prinsip akuntansi yang berlaku di Indonesia.

Salah satu bentuk organisasi nirlaba yang sering kita temui adalah yayasan. Yayasan adalah badan hukum yang kekayaannya terdiri dari kekayaan yang dipisahkan dan diperuntukkan untuk mencapai tujuan tertentu di bidang sosial, keagamaan, dan kemanusiaan (Menurut UU No.16 Tahun 2001). Sebagai entitas nirlaba, yayasan memperoleh dana berupa sumbangan dari donatur, masyarakat, dan pemerintah untuk melangsungkan kegiatan operasionalnya. Walaupun para pemberi dana tidak mengharapkan pengembalian atas dana yang telah diberikan, pihak yayasan harus mampu membuat laporan keuangan sebagai bentuk pertanggungjawaban atas transaksi dana, laporan keuangan tersebut sekaligus berfungsi sebagai alat pengambilan keputusan oleh berbagai pihak.

Yayasan Pendidikan Pondok Pesantren Al-Kairiyah merupakan salah satu bentuk yayasan, yang bergerak dibidang pendidikan berbasis islam beralamat di Jl. KH Abdul Aziz No.66 Desa Kauman Kecamatan Tempurejo Kabupaten Jember. Yayasan Pendidikan Pondok Pesantren Al-Khairiyah ini semula hanya terdiri dari beberapa anak-anak yang menimba ilmu di daerah lingkungan sekitar saja, tetapi setiap tahunnya semakin bertambah menunjukkan bahwa yayasan ini mempunyai kualitas pelayanan yang baik. Yayasan Pondok Pesantren Al-Khairiyah tidak memberikan beban yang berat kepada anak-anak dalam mencari ilmu, dengan meniadakan pembayaran uang bulanan.

Prinsip yang selalu diutamakan dalam Yayasan Pendidikan Pondok Pesantren Al-Khairiyah bagi pihak pengajar/ guru adalah "Jika niat seorang guru untuk mengajar murid hanya untuk mencari gaji yang tinggi, maka tidak diperkenankan untuk mengajar di yayasan ini, yayasan ini selain untuk menambah amal ibadah diakhirat juga untuk memberikan ilmu yang bermanfaat bagi para muridnya meskipun dengan gaji yang sedikit namun barokah". Untuk memberikan pelayanan yang lebih baik lagi bagi mereka salah satunya harus ditopang dengan materi, dalam hal ini dana masih minim, dan banyak kebutuhan yang masih diperlukan dalam aktivitas proses belajar mengajar.

Sebagai salah satu organisasi nirlaba, Yayasan Pendidikan Pondok Pesantren Al-Kahiriyah harus menerapkan PSAK No. 45 dalam melakukan penyusunan laporan keuangannya. Pihak yayasan menyadari bahwa belum bisa menyusun laporan keuangan sesuai dengan standar akuntansi yang berlaku di Indonesia. Pencatatan hanya dilakukan secara sederhana dan membutuhkan perbaikan. Karena dengan dilakukan pencatatan yang sederhana pertanggungjawaban dari suatu laporan keuangan kurang memberikan informasi yang jelas dan tepat, sehingga yayasan ini menerima dana dari bantuan pemerintah dan wali murid. Bantuan dari wali murid hanya dilakukan setiap tahun sekali, digunakan untuk pembayaran ujian akhir setiap siswa ketika menghadapi Ujian Nasional. Yayasan ini setiap tahunnya mengalami penurunan serta kurang bisa menarik donatur atau penyumbang dana lainnya.

Organisasi Nirlaba sering juga disebut dengan istilah organisasi non profit atau organisasi non bisnis. Jika dilihat dari istilah "nirlaba", maka dapat kita lihat bahwa organisasi nirlaba ini didirikan dengan alasan-alasan di luar dari usaha memperoleh laba untuk para pemilik atau investor. Menurut Salusu (2003) Organisasi non profit adalah organisasi atau badan yang tidak menjadikan keuntungan sebagai motif utamanya dalam melayani masyarakat. Atau disebut juga sebagai korporasi yang tidak membagikan keuntungan sedikitpun kepada para anggota, karyawan serta eksekutifnya.

Organisasi nirlaba atau bisnis nonlaba bertujuan untuk melayani beberapa kelompok stakeholder, yang anggotanya lebih luas dari pada stockholders. Stakeholders meliputi board of trustees, manajer, pegawai atau karyawan, kreditur, supplier, konsumen dan masyarakat sekitar (Sartono, 2000).

Karakteristik organisasi nirlaba sangat berbeda dengan organisasi bisnis yang berorientasi untuk memperoleh laba. Perbedaan utama yang mendasar terletak pada cara organisasi nirlaba memperoleh sumber daya dibutuhkan untuk melakukan berbagai aktivitas operasionalnya. Organisasi nirlaba 
memperoleh sumber daya dari sumbangan para anggota dan para penyumbang lain yang tidak mengharapkan imbalan apapun dari organisasi nirlaba tersebut (PSAK No. 45: 2015).

Ikatan Akuntan Indonesia (2004) menyatakan bahwa laporan keuangan keuangan merupakan bagian dari proses pelaporan keuangan. Laporan keuangan yang lengkap biasanya meliputi neraca, laporan laba-rugi, laporan perubahan posisi keuangan yang dapat disajikan dalam berbagai cara misalnya, sebagai laporan arus kas, atau laporan arus dana, catatan dan laporan lain serta materi penjelasan yang merupakan bagian integral dari laporan keuangan. Disamping itu juga termasuk skedul dan informatika tambahan yang berkaitan dengan laporan tersebut, misalnya, informatika keuangan segmen industri dan geografis serta pengungkapan pengaruh perubahan harga.

Beberapa pendapat tentang laporan keuangan, antara lain : Menurut Standar Akuntansi Keuangan (2009) Laporan keuangan merupakan bagian dari proses pelaporan keuangan yang lengkap, biasanya meliputi neraca, laporan laba rugi, laporan posisi keuangan (yang dapat disajikan dalam beberapa cara, laporan arus kas dan laporan arus dana), catatan dan laporan lain serta materi penjelasan yang merupakan bagian integral dari laporan keuangan, disamping itu juga segmen industri dan geografis serta pengungkapan perubahan harga. Menurut Munawir (2002), laporan keuangan pada dasarnya adalah hasil dari proses akuntansi yang dapat digunakan sebagai alat untuk berkomunikasi antara data keuangan atau aktivitas suatu perusahaan dengan pihak-pihak yang berkepentingan dengan data atau aktivitas perusahaan tersebut.

Tujuan utama laporan keuangan adalah menyediakan informasi yang relevan untuk memenuhi kepentingan pemberi sumber daya yang tidak mengharapkan pembayaran kembali, anggota, kreditur, dan pihak lain yang menyediakan sumber daya bagi entitas nirlaba (PSAK No.45: 2015). Menurut (PSAK No.45) Laporan posisi keuangan merupakan nama lain dari neraca pada laporan keuangan lembaga komersial. Laporan ini memberikan informasi mengenai besarnya aset atau harta lembaga dan sumber perolehan aset tadi (bisa dari hutang atau dari aktiva bersih) pada satu titik tertentu.

Ronny Hendrawan (2011) menyatakan Hasil analisis kualitatif menunjukkan tidak terdapat perbedaaan yang signifikan untuk 8 indikator yang digunakan. Hasil analisis kuantitatif menunjukkan tidak ada perbedaan perhitungan antara laporan keuangan RSUD Kota Semarang dengan PSAK No. 45.

Laporan aktivitas mencakup entitas nirlaba secara keseluruhan dan menyajikan perubahan jumlah aset neto selama suatu periode. Perubahan aset neto dalam laporan aktivitas tercermin pada aset neto ekuitas dalam posisi keuangan. Laporan arus kas menunjukkan arus uang kas masuk dan keluar untuk suatu periode. Periode yang dimaksud adalah periode sama dengan yang digunakan oleh laporan aktivitas. Catatan atas laporan keuangan meliputi penjelasan naratif atau rincian jumlah yang tertera dalam laporan posisi keuangan, laporan aktivitas, dan laporan arus kas serta informasi tambahan seperti kewajiban kontinjensi dan komitmen. Catatan atas laporan keuangan juga mencakup informasi yang diharuskan dan dianjurkan untuk diungkapkan dalam Pernyataan Standar Akuntansi Keuangan serta pengungkapan-pengungkapan lain yang diperlukan untuk menghasilkan penyajian laporan keuangan secara wajar.

\section{Metode}

Penelitian ini menggunakan desain penelitian deskriptif kualitatif. Menurut Bungin (2011) penelitian menggunakan format deskriptif kualitatif bertujuan untuk menggambarkan, meringkaskan berbagai kondisi, berbagai situasi, atau berbagai fenomena realita sosial yang ada di masyarakat yang menjadi objek penelitian, dan berupaya menarik realita itu ke permukaan sebagai suatu ciri, karakter, sifat, model, tanda, atau gambaran tentang kondisi, situasi, ataupun fenomena tertentu.

Data yang digunakan dalam penelitian ini adalah data dokumenter menurut Indriantoro (2002) yaitu jenis data penelitian yang antara lain berupa: faktur, jurnal, surat-surat, notulen hasil rapat, memo, atau dalam bentuk laporan program. Sumber data yang digunakan dalam penelitian ini ada dua, yaitu: 1 . Data primer merupakan sumber data penelitian yang diperoleh secara langsung dari sumber asli, tidak melalui media perantara (Indrianto, 2012). 2. Data sekunder merupakan penelitian yang diperoleh peneliti secara tidak langsung melalui media perantara, diperoleh dan dicatat oleh pihak lain ( Indrianto, 2012).

Metode yang digunakan peneliti dalam pengumpulan data adalah 1. wawancara merupakan teknik pengumpulan data dalam metode survei yang menggunakan pertanyaan secara lisan kepada subyek penelitian (Indriantoro, 2012). 2. Metode dokumenter adalah metode yang di gunakan untuk mencari dan mengumpulkan data mengenai hal-hal yang berupa catatan, transkip, buku, surat kabar, majalah, notulen, rapot, agenda dan lain sebagainya (Arikunto, 2006).

Tahapan-tahapan dalam penelitian ini adalah: 
(1) Pengumpulan data, yaitu mengumpulkan data dilokasi penelitian dengan wawancara, observasi dan dokumentasi dengan menentukan strategi pengumpulan data yang tepat. Salah satu datanya berupa laporan keuangan yang digunakan Yayasan Pendidikan Pondok Pesantren Al-Khairiyah, (2) Mengidentifikasi data laporan keuangan yang telah diterapkan Yayasan Pendidikan Pondok Pesantren AlKhairiyah berdasarkan PSAK No.45 (3) Mengkonstruksi data laporan keuangan yang diterapkan Yayasan Pendidikan Pondok Pesantren Al-Khairiyah sesuai dengan laporan keuangan berdasarkan PSAK No.45 (4) Menyimpulkan hasil penelitian yang telah dilakukan pada Yayasan Pendidikan Pondok Pesantren AlKhairiyah.

\section{Hasil dan pembahasan}

Yayasan pendidikan pondok pesantren al-khairiyah adalah sebuah organisasi nirlaba yang bergerak dibidang pendidikan dan berada di naungan kementerian agama, yang didirikan pada tahun 2010 sesuai dengan No.SK pendirian Kd.13.09/4/Yayasan/206/2010. Yayasan ini berada di Desa Tempurejo, Kecamatan Tempurejo, Kabupaten Jember. Yayasan ini terkenal dengan bidang keagamaannya yang kuat dan pelayanan yang baik kepada masyarakat. Yayasan Pendidikan Pondok Pesantren Al-Khairiyah ini dahulunya hanya sebuah lahan kosong yang tidak terpakai dan tidak memberikan manfaat bagi lingkungan sekitar.

Tabel 1. Laporan Keuangan pada Yayasan Pendidikan Pondok Pesantren Al-Khairiyah

\section{Buku Kas}

Bulan April 2017

\begin{tabular}{|c|c|c|c|c|}
\hline Tanggal & Uraian & $\begin{array}{c}\text { Penerimaan } \\
\text { (Debit) }\end{array}$ & $\begin{array}{c}\text { Pengeluaran } \\
\text { (Kredit) }\end{array}$ & Saldo \\
\hline & Saldo bulan lalu & - & - & - \\
\hline $\begin{array}{l}\text { 04-Apr- } \\
2017\end{array}$ & Penerimaan Kas & 70.300 .000 & - & 70.300 .000 \\
\hline $\begin{array}{l}\text { 04-Apr- } \\
2017\end{array}$ & Penerimaan dana zakat & 500.000 & - & 70.800 .000 \\
\hline $\begin{array}{l}\text { 04-Apr- } \\
2017\end{array}$ & $\begin{array}{l}\text { Dibayarkan } \\
\text { penggandaan tugas guru } \\
\text { dan jadwal pelajaran }\end{array}$ & - & 292.000 & 70.508 .000 \\
\hline $\begin{array}{l}\text { 04-Apr- } \\
2017\end{array}$ & $\begin{array}{l}\text { Dibayarkan } \\
\text { penggandaan RPP }\end{array}$ & - & 894.000 & 69.614 .000 \\
\hline $\begin{array}{l}\text { 04-Apr- } \\
2017\end{array}$ & $\begin{array}{l}\text { Dibayarkan } \\
\text { penggandaan jurnal dan } \\
\text { absensi }\end{array}$ & - & 640.000 & 68.974 .000 \\
\hline $\begin{array}{l}\text { 04-Apr- } \\
2017\end{array}$ & $\begin{array}{l}\text { Dibayarkan perbaikan } \\
\text { instalasi listrik }\end{array}$ & - & 250.000 & 68.724 .000 \\
\hline 04-Apr- & Dibayarkan pembelian & - & 950.000 & 67.774 .000 \\
\hline 2017 & $\begin{array}{l}\text { ATK (kertas HVS, spidol, } \\
\text { isi stapler, dll) }\end{array}$ & & & \\
\hline 04-Apr- & Dibayarkan perbaikan & - & 940.000 & 66.834 .000 \\
\hline 2017 & kamar madi yayasan & & & \\
\hline 04-Apr- & Dibayarkan perbaikan & - & 500.000 & 66.334 .000 \\
\hline
\end{tabular}




\begin{tabular}{|c|c|c|c|c|}
\hline 2017 & printer yayasan & & & \\
\hline 04-Apr- & Dibayarkan pembelian & - & 480.000 & 65.854 .000 \\
\hline \multirow[t]{2}{*}{2017} & tinta printer 6 botol & & & \\
\hline & $@ 80.000$ & & & \\
\hline 04-Apr- & Dibayarkan pembelian & - & 200.000 & 65.654 .000 \\
\hline 2017 & pulsa modem & & & \\
\hline 04-Apr- & Dibayarkan perbaikan & - & 450.000 & 65.204 .000 \\
\hline 2017 & pintu yayasan & & & \\
\hline 04-Apr- & Dibayarkan pembelian & - & 150.000 & 65.054 .000 \\
\hline 2017 & air mineral galon & & & \\
\hline 04-Apr- & Dibayarkan kegiatan & - & 720.000 & 64.334 .000 \\
\hline 2017 & ekstrakurikuler & & & \\
\hline 04-Apr- & Penerimaan dana infaq & 372.000 & - & 64.706 .000 \\
\hline \multicolumn{5}{|l|}{2017} \\
\hline 04-Apr- & Dibayarkan gaji guru & - & 3.515 .000 & 61.191 .000 \\
\hline \multicolumn{5}{|l|}{2017} \\
\hline 04-Apr- & Dibayarkan jasa & - & 300.000 & 60.891 .000 \\
\hline 2017 & kebersihan yayasan & & & \\
\hline 04-Apr- & Dibayarkan pembelian & - & 350.000 & 60.541 .000 \\
\hline 2017 & sarana kebersihan & & & \\
\hline 04-Apr- & Dibayarkan pembelian & - & 100.000 & 60.441 .000 \\
\hline 2017 & token listrik yayasan & & & \\
\hline 04-Apr- & Dibayarkan pembelian & - & 972.000 & 59.469 .000 \\
\hline 2017 & ATK & & & \\
\hline 04-Apr- & Dibayarkan perbaikan & - & 500.000 & 58.969 .000 \\
\hline 2017 & laptop yayasan & & & \\
\hline 04-Apr- & Dibayarkan isi ulang air & - & 150.000 & 58.819 .000 \\
\hline 2017 & mineral@15.000 & & & \\
\hline 04-Apr- & Dibayarkan pembelian & - & 200.000 & 58.619 .000 \\
\hline 2017 & pulsa modem & & & \\
\hline 04-Apr- & Dibayarkan kegiatan & - & 720.000 & 57.899 .000 \\
\hline 2017 & ekstrakurikuler & & & \\
\hline 04-Apr- & Dibayarkan gaji guru & - & 3.515 .000 & 54.384 .000 \\
\hline \multicolumn{5}{|l|}{2017} \\
\hline 04-Apr- & Dibayarkan jasa & - & 300.000 & 54.084 .000 \\
\hline 2017 & kebersihan yayasan & & & \\
\hline 04-Apr- & Dibayarkan pembelian & - & 480.000 & 53.604 .000 \\
\hline \multirow[t]{2}{*}{2017} & tinta printer 6 botol & & & \\
\hline & $@ 80.000$ & & & \\
\hline
\end{tabular}




\begin{tabular}{|c|c|c|c|c|}
\hline 04-Apr- & Dibayarkan pembelian & - & 100.000 & 53.504 .000 \\
\hline 2017 & token listrik yayasan & & & \\
\hline 04-Apr- & Dibayarkan & - & 450.000 & 53.054 .000 \\
\hline \multirow[t]{3}{*}{2017} & penggandaan brosur & & & \\
\hline & penerimaan anak didik & & & \\
\hline & baru & & & \\
\hline 04-Apr- & Dibayarkan pembelian & - & 932.000 & 52.122 .000 \\
\hline 2017 & ATK & & & \\
\hline 04-Apr- & Dibayarkan pembelian & - & 480.000 & 51.642 .000 \\
\hline \multirow[t]{2}{*}{2017} & tinta printer 6 botol & & & \\
\hline & $@ 80.000$ & & & \\
\hline 04-Apr- & Dibayarkan & - & 300.000 & 51.342 .000 \\
\hline \multirow[t]{2}{*}{2017} & penggandaan peralatan & & & \\
\hline & yayasan & & & \\
\hline 04-Apr- & Dibayarkan isi ulang air & - & 150.000 & 51.192 .000 \\
\hline 2017 & mineral @15.000 & & & \\
\hline 04-Apr- & Dibayarkan jasa & - & 300.000 & 50.892 .000 \\
\hline 2017 & kebersihan yayasan & & & \\
\hline 04-Apr- & Dibayarkan bahan ujian & - & 555.000 & 50.337 .000 \\
\hline \multicolumn{5}{|l|}{2017} \\
\hline 04-Apr- & Dibayarkan & - & 462.000 & 49.875 .000 \\
\hline \multirow[t]{2}{*}{2017} & penggandaan naskah try & & & \\
\hline & out & & & \\
\hline 04-Apr- & Dibayarkan & - & 924.000 & 48.951 .000 \\
\hline \multirow[t]{2}{*}{2017} & penggandaan naskah try & & & \\
\hline & out yayasan & & & \\
\hline 04-Apr- & Dibayarkan ATK & - & 415.000 & 48.536 .000 \\
\hline 2017 & persiapan ujian & & & \\
\hline 04-Apr- & Dibayarkan & - & 986.000 & 47.550 .000 \\
\hline 2017 & penggandaan soal ujian & & & \\
\hline 04-Apr- & Dibayarkan pembelian & - & 200.000 & 47.350 .000 \\
\hline 2017 & pulsa modem & & & \\
\hline 04-Apr- & Dibayarkan perbaikan & - & 1.000 .000 & 46.350 .000 \\
\hline 2017 & ruang yayasan & & & \\
\hline 04-Apr- & Dibayarkan kegiatan & - & 720.000 & 45.630 .000 \\
\hline 2017 & Ekstrakurikuler & & & \\
\hline 04-Apr- & Dibayarkan gaji guru & - & 3.515 .000 & 42.115 .000 \\
\hline \multicolumn{5}{|l|}{2017} \\
\hline 04-Apr- & $\begin{array}{l}\text { Dibayarkan pembelian } \\
\text { token listrik yayasan }\end{array}$ & - & 100.000 & 42.015 .000 \\
\hline
\end{tabular}


2017

06-Apr- Dibayarkan pembelian

08-Aprtoken listrik yayasan

2017

Dibayarkan pembelian

10-Aprair mineral galon @15.000

2017

Dibayarkan pembelian pulsa modem

Laporan Posisi Keuangan yang dibuat oleh Yayasan Pendidikan Pondok Pesantren Al-Khairiyah Tempurejo belum menerapkan PSAK Nomor 45 dalam membuat laporan keuangan yayasan. Maka dari itu saya merekontruksi laporan keuangan masjid yang sesuai dengan PSAK 45 yang terdiri dari dari Asset Lancar, Liabilitas Jumlah Dana. Yayasan Pendidikan Pondok Pesantren Al-Khairiyah masih belum membuat laporan aktivitas karena masih belum ada tenaga ahli akuntansi dalam menyusun laporan aktivitas yang sesuai dengan PSAK No.45. Belum ada perubahan Aset Neto Terikat Temporer di Yayasan Pendidikan Pondok Pesantren Al-Khairiyah. Catatan atas laporan keuangan merupakan catatan yang menjelaskan mengenai gambaran umum organisasi, ikhtisar kebijakan akuntansi, serta penjelasan pospos laporan keuangan dan informasi penting lainnya. Dilihat dari rekonstruksi laporan keuangan Yayasan Pendidikan Pondok Pesantren Al-Khairiyah yang dibuat belum mengacu pada PSAK No. 45. 
Laporan keuangan yang telah ditampilkan dan di publikasi seperti ini memang cukup mudah dipahami oleh masyarakat umum (donatur), karena sudah cukup transparan dalam melaporkan keuangan kepada masyarakat. Laporan keuangan Yayasan Pendidikan Pondok Pesantren Al-Khairiyah diterbitkan dalam periode setiap semester (6 bulan sekali). Laporan keuangan setiap semester ditujukan untuk pihak internal dan untuk masyarakat umum (donatur) sebagai bentuk akuntabilitas.

Catatan atas laporan keuangan meliputi penjelasan naratif atau rincian jumlah yang tertera dalam laporan posisi keuangan, laporan aktivitas, dan laporan arus kas serta informasi tambahan seperti kewajiban kontinjensi dan komitmen. Catatan atas laporan keuangan juga mencakup informasi yang diharuskan dan dianjurkan untuk diungkapkan dalam Pernyataan Standar Akuntansi Keuangan serta pengungkapan-pengungkapan lain yang diperlukan untuk menghasilkan penyajian laporan keuangan secara wajar. Laporan Keuangan Yayasan Pendidikan Pondok Pesantren Al-Khairiyah belum menerapkan PSAK No.45 laporan keuangannya masih dalam bentuk sederhana yaitu pemasukan dan pengeluaran. Setelah penelitian ini Yayasan Pendidikan Pondok Pesantren Al-Khairiyah dapat membuat Laporan Keuangan yang sesuai dengan PSAK No.45.

\section{Simpulan dan saran}

(1) Laporan keuangan Yayasan Pendidikan Pondok Pesantren Al-Khairiyah di sajikan sangat sederhana, yakni pencatatan pemasukan dan pengeluaran, (2) Penyusunan laporan keuangan Yayasan Pendidikan Pondok Pesantren Al-Khairiyah belum sesuai PSAK No. 45. Berdasarkan pengamatan yang telah dilakukan peneliti memperlihatkan bahwa penyajian informasi keuangan Yayasan Pendidikan Pondok Pesantren Al-Khairiyah sebagai bentuk akuntabilitas dan transparansi telah dilakukan dengan dua cara yaitu: (a) Diumumkan setiap 6 bulan sekali, yaitu tepat pada akhir semester, (b) Ditempel dipapan informasi yang telah disediakan oleh pengurus Yayasan Pendidikan Pondok Pesantren AlKhairiyah, (3) Laporan keuangan yang dilakukan pengurus Yayasan Pendidikan Pondok Pesantren AlKhairiyah belum sesuai dengan standar keuangan PSAK No. 45 karena sangat sederhana yaitu bentuknya yang masih menggunakan metode accrual basic dengan pencatatan pemasukan dan pengeluaran. Penyusunan laporan keuangan Yayasan Pendidikan Pondok Pesantren Al-Khairiyah berdasarkan PSAK No. 45 sudah dibahas di bab sebelumnya.

Saran peneliti yang mungkin bermanfaat pada Yayasan Pendidikan Pondok Pesantren Al-Khairiyah: (1) Mendorong konsistensi penggunaan akuntansi sebagai instrumen untuk mendorong kejujuran dan akuntabilitas akan menggeser pemahaman menjaga kehormatan diri, wibawa dan citra kepemimpinan pengurus Yayasan Pendidikan Pondok Pesantren Al-Khairiyah, (2) Sebaiknya bentuk laporan keuangan disesuaikan dengan PSAK No. 45 serta lengkapi setiap data laporan keuangan dengan catatan atas laporan keuangan, (3) Konstruk yang dihasilkan peneliti agar menjadi bahan untuk pembelajaran bagi pengurus Yayasan Pendidikan Pondok Pesantren Al-Khairiyah dalam mengelola laporan keuangan.

\section{Daftar Rujukan}

Badan Penerbit Universitas Muhammadiyah Jember. 2014. Pedoman Penyusunan Skripsi dan Buku Konsultasi, Fakultas Ekonomi. Jember: Universitas Muhammadiyah Jember.

Bambang Supomo dan Nur Indrianto. 1999. Metodologi Penelitian Bisnis Untuk Akuntansi dan Manajemen. Yogyakarta: BPFE.

Bastian, Indra. 2007. Akuntansi Yayasan dan Lembaga Publik. Jakarta: Erlangga.

Bugin, Burhan. 2011. Penelitian Kualitatif. Jakarta: Kencana.

David Hasibuan. 2010. Penerapan PSAK No. 45 Pada Yayasan Mandiri Anak Bangsa Nusantara Dalam Kaitannya Dengan Kualitas Informasi Pelaporan Keuangan (PSAK No. 45 Application at Yayasan Mandiri Anak Bangsa Nusantara in Relation to Financial Statement Information). Jurnal Ilmiah Kesatuan Nomor 1 Volume 12.

Ikatan Akuntansi Indonesia. 2015. Pernyataan Standar Akuntansi Keuangan No.45. Jakarta: Salemba 4.

Mei Witria Ulfa, R. Anastasia Endang Susilawati, dan Abdul Halim. 2014. Analisis Penerapan Pernyataan Standar Akuntansi Keuangan (PSAK) No. 45 Tentang Pelaporan Keuangan Organisasi Nirlaba (Studi 
Kasus Pada Smk Negeri 4 Malang). Journal Riset Mahasiswa Akuntansi (JRMA) Volume: 02, Nomor: 01, April.

Miles, Mattew B dan A, Michael Huberman. 2007. Analisis Data Kualitatif Buku sumber tentang metodemetode baru. Jakarta: Universitas Indonesia.

Mohammad Nazir, 2005. Metode Penelitian. Jakarta: Ghalia.

Moleong, Lexy J. Metode Penelitian Kualitatif Edisi Revisi. Bandung: PT. Remaja Rosidakarya.

Nainggolan, Pahala. 2007. Akuntansi Keuangan Yayasan dan Nirlaba Sejenis. Jakarta: PT. Raja grafindopersada.

Ratna Pertiwi. 2016. Analisis Penerapan Psak No. 45 Tentang Pelaporan Keuangan Organisasi Nirlaba (Non Profit) Terhadap Penyajian Laporan Keuangan Pada Yayasan Oikumene Kalimantan Barat. Jurnal Kajian Ilmiah Akuntansi Fakultas Ekonomi UNTAN (KIAFE). Vol. 5 No 3.

Risnani, R. (2013). Analisis Penerapan PSAK Nomor 45 Tentang Pelaporan Keuangan Organisasi Nirlaba Pada Rumah Sakit Berstatus Badan Layanan Umum Daerah RSUD “Kanjuruhan” Kepanjen. Jurnal Riset Mahasiswa Akuntansi, 1(1). Retrieved from http://ejournal.unikama.ac.id/index.php/jrma/article/view/1.

Ronny Hendrawan. 2011. Analisis Penerapan Psak No. 45 Tentang Pelaporan Keuangan Organisasi Nirlaba Pada Rumah Sakit Berstatus Badan Layanan Umum. Jurnal Ekonomi Universitas Diponegoro. Vol 2 No.1.

Sugiyono, 2007. Metode Penelitian Bisnis. Bandung: Alfabeta.

Sartono, Agus. 2000. Manajemen Keuangan. Yogyakarta: BPFE.

Wawan Sukmana, dan Yesi Gusman. 2008. Pengaruh Penyajian Laporan Keuangan Berdasarkan Psak No. 45 Tentang Pelaporan Keuangan Organisasi Nirlaba Dan Penerapan Total Quality Management Terhadap Kinerja Yayasan (Survei Pada Yayasan Yang Mengelola Perguruan Tinggi Swasta Di Tasikmalaya). Jurnal Akuntansi FE Unsil, Vol. 3, No. 1. 